CZASOPISMO INŻYNIERII LA¿OWEJ, ŚRODOWISKA I ARCHITEKTURY JOURNAL OF CIVIL ENGINEERING, ENVIRONMENT AND ARCHITECTURE JCEEA, t. XXXIV, z. 64 (2/II/17), kwiecień-czerwiec 2017, s. 121-130, DOI: 10.7862/rb.2017.86

\author{
Anna BAZAN-KRZYWOSZAŃSKA ${ }^{1}$ \\ Maria MRÓWCZYŃSKA ${ }^{2}$ \\ Marta SKIBA ${ }^{3}$
}

\title{
A POLICY OF DEVELOPMENT OF POST-MINING LAND ON THE EXAMPLE OF ZIELONA GÓRA
}

\begin{abstract}
The article is an introduction to the issue of shaping post-mining areas and the former coal mine sites of Zielona Góra, (lubuskie voivodeship). One of the characteristic geological processes, shaping the current surface of the mentioned area were glaciotectonic deformations - a set of processes related to icecaps movements, that have brought the deposits of lignite near the surface. This allowed to their partial exploration in the past. In the 19th century, around Zielona Góra, several lignite mines were in use. Some of them have already been completely forgotten and no documents or information as a proof of their previous existence remained. Currently, the most important raw material in the natural surroundings of the city are natural aggregates such as sands and gravels and different kinds of ceramic raw materials (loam, clay). The city of Zielona Góra, seeking new investment areas, develops further areas, including those that have been former mine sites for at least 70 years. The areas have not undergone reclamation, in accordance with the current procedure under the law. Although the reclamation of post-mining areas, both technical and biological, is a responsibility of a mining plant and should be consistent with the law, there have not been institutions covered by the above obligation for over 70 years.

The historical value of the city's post-mining areas, as well as the problems associated with the protection of nature and landscape, resulting inter alia from the act of 16 April 2004 on the protection of nature (Off. J. of 2015 item 1651, as amended), and the act of 24 April 2015 on amending certain acts due to the strengthening of the tools of landscape protection (Off. J. of 2015 items 774, 1688) [13], indicate a need for action, aimed at maintaining documentation and the identity of the place. All sorts of sports and leisure or park use can be provided for such areas [9]. It is necessary, however to determine the directions of development, within the documents shaping urban spatial policy, that would indicate the purpose and way of development of the mentioned areas.
\end{abstract}

Keywords: land use, urban policy, planning documents, post-mining areas and former mine sites

\footnotetext{
1 Autor do korespondencji / corresponding author: Anna Bazan-Krzywoszańska, University of Zielona Góra, Faculty of Civil engineering, Architecture and Environmental Engineering, ul. Licealna 9, 65-246 Zielona Góra; A.Bazan@aiu.uz.zgora.pl

${ }^{2}$ Maria Mrówczyńska, University of Zielona Góra, Faculty of Civil engineering, Architecture and Environmental Engineering M.Mrowczynska@uz.zgora.pl

${ }^{3}$ Marta Skiba, University of Zielona Góra, Faculty of Civil engineering, Architecture and Environmental Engineering M.Skiba@aiu.uz.zgora.pl
} 


\section{Introduction}

The restoration of the degraded areas to the status of economic interest or giving them new purpose occurs by their development. In accordance with the Act of 27 March 2003 on spatial planning and development (Off. J. of 2016 item 778 as amended) [15] the legislator requires to indicate areas that need transformations or rehabilitation in the planning document, which is a municipal study of spatial development conditions and directions (article 10, paragraph 2, subparagraph 14) and in a local zoning plan, (article 15, paragraph 3, subparagraph 3). On the basis of the article 104 paragraph 1 of the Act of 9 June 2011 on the geological and mining law (Off. J. of 2016 item 1131) [17], mining areas and sites were considered as the special case of sites exposed to significant environmental effects of the activities referred to in the concessions. Due to the article 104 paragraph 2 of the act, for the sites mentioned above the legislator provides the implementation of the local zoning plan, in accordance with the act on spatial planning and development. The obligation to do so derives directly from article 72 paragraphs 1, 2 and 3 of the Act of 27 April 2001 on the environmental protection (Off. J. of 2016 item 672 as amended) [14], in which the legislator indicated that municipal planning documents, when allocating land to the certain objectives and determining the tasks related to their development in the land structure, shall consider proposals that allow the maintenance of the natural balance and the rational management of natural resources, as well as the proper living conditions. This directly resulted in the regulation that, the management of areas degraded by human activity shall be determined in the municipal planning documents.

Provision of article 129 paragraph 2 of the Act of 9 June 2011 on the geological and mining law (Off. J. of 2016 item 1131) [17] provides that the reclamation of post-mining activities land shall apply the provisions of the Farm and Woodland Conservation Act of 3 February 1995 (Off. J. of 2015 item 909 as amended) This means that the provisions of the Farm and Woodland Conservation Act shall apply in case of the reclamation of any land type of use, changed as a result of mining activities. Pos-mining land reclamation, should be carried out taking into account the principles deriving from the mentioned act.

In municipal planning and environmental documents, also in the context of indirect documents, carried out for the purposes of spatial planning and development procedures (ecophysiographic studies, estimation of an impact of planning documents on the environment) reclamation of degraded land is connected with the objective to achieve in the form of specific function, optimal for a certain land and its use [2].

Possibilities of a land remediation in a preferred direction is determined by many factors, some of which are of minor importance, while others are decisive. Among the factors determining the choice of direction of the reclamation there are following: the current way of land use, natural factors, climatic conditions, the nature and quality of the surrounding areas, hydrological conditions, soil 
conditions, social-economic factors, technical-economic factors, the costs and benefits obtained in the end, as well as technical and technological feasibility of the planned investment.

Among these factors, the natural, constant in time factors, which include, such as hydrological conditions indicating the final land destination, for example water reservoir should be crucial when choosing the direction of the post-mining heading development. Soil conditions, the nature and quality of the surrounding should have additional importance only. However, in practice, technical economic factors usually have decisive influence on the scope of the remediation work [7].

\section{Zielona Góra - historical background of mining areas}

Zielona Góra became involved in lignite in 1838, when its deposits were discovered around the Preisler (Peisker) mill near Ochla. They were discovered by Carl Adolph Pohlenz, a merchant from Zielona Góra, whose name in the 1930s of the 20th century was given to one of the most important deposits of these areas and to a mining shaft. Another study, carried out in the city and in the surrounding area, showed the presence of the local deposits of lignite, mostly in the Southwestern part, and near the city boundaries. As a result, in the 19th century, several lignite mines were in use around Zielona Góra. Some of them have already been completely forgotten and no documents or information about them left.

Lignite around Zielona Góra occurs most commonly under loams, which were used as a raw material for bricks manufacture. Mines had very small extraction and fulfilled only local needs of the inhabitants of the surrounding villages or local industry such as a brickyard (figs 1,2). Pre-war mining plants produced coal, building wooden adits that were deconstructed after the completion of the deposit exploration, which has made an extraction of coal possible after the war, especially in forest areas. These mines due to the industry development and an increase in production by larger, more competitive mines were becoming unprofitable. Most of them ran the operation by several-decades, using one deposit. Therefore, it is very difficult to find the exact location of some of them.

According to the inventory of industrial plants, in 1936 there were the following underground lignite mines in the surroundings of Zielona Góra:

a) „Consolidierte Grünberger Gruben”, Grünberg (Zielona Góra),

b) „Braunkohlenwerk „Ferdinandsgrube“, Loos bei Grünberg (Łazy),

c) „Consolidierte Emmagrube“, Bielitz bei Freystadt (Bielice Kożuchowskie),

d) Inactive mine "Freia" in Niesky bei Rothenburg (Nietków near Czerwieńsk) (fig. 1).

The largest and longest-running mine in the area were "United Mines of Zielona Góra", or "Konsolidierte Grünberger Gruben" that were active apart from the city area, also in Rybno, Wilkanów, Świdnica, Letnica and Słone (fig. 1). The mines of Zielona Góra were subject to the authority of Mining Office in Zgorzelec, which managed area from Zgorzelec through Greater Poland 


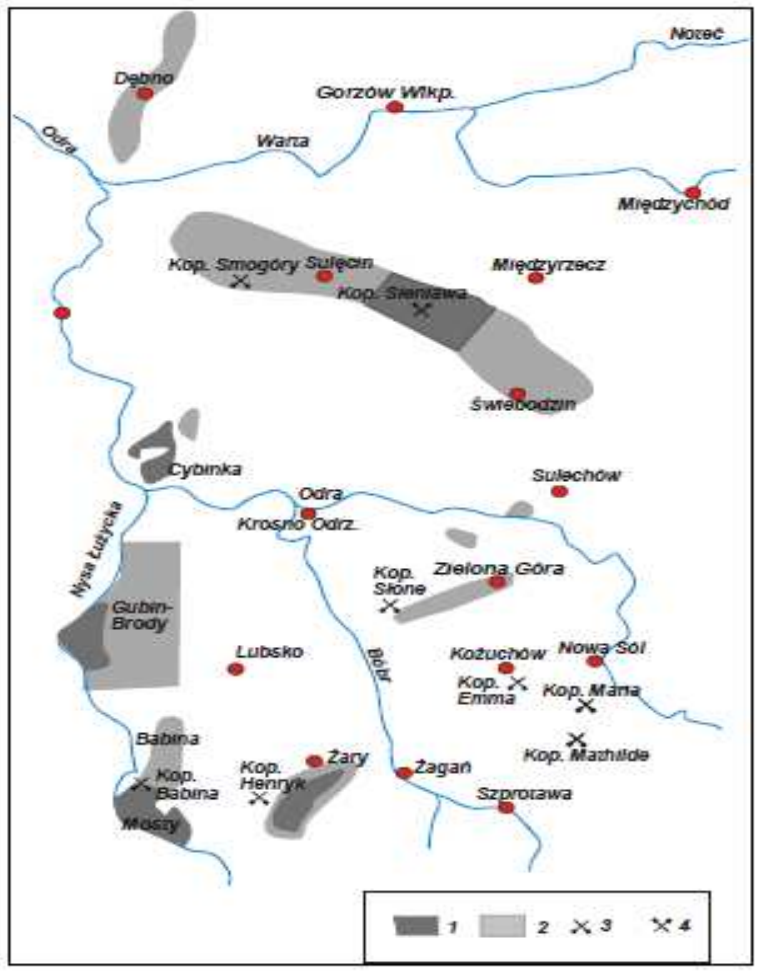

Fig. 1. Deposits of lignite in Lubuskie: 1 - documented, 2 - deposits of perspective, 3 - significant closed mines, 4 - active mines. Source: [5, p. 47]

Rys. 1. Złoża węgla brunatnego na terenie Ziemi Lubuskiej: 1 - złoże udokumentowane, 2 - złoża perspektywiczne, 3 - ważniejsze nieczynne kopalnie, 4 - czynne kopalnie. Źródło: [5, s. 47]

to East Prussia, being the part of the District of Wrocław. Development of opencast lignite mines in Lusatia, less than $100 \mathrm{~km}$ from Zielona Góra, as a cheaper production started the decline of the mines of Zielona Góra Their closure was announced at the end of 1937, however, the last legal excavations are dated 1945-1946, when the electricity supply from Frankfurt stopped, and delivery of coal from Silesia delayed [5].

Mysteriously, the history of mining and the extraction of lignite in the city of Zielona Góra has almost been completely forgotten, and the evidence is the fact that this topic was the subject of research, even in the context of the regional history, in a very small amount. Also the archives has not kept much of records concerning the mines and their way of functioning in these lands [3, 4].

\section{Documents shaping urban spatial policy}

The development of the urban space of Zielona Gora, in the postwar period was subordinated to the development of the main transportation routes. Residen- 
tial areas, after filling in undeveloped areas within the existing urban structure were, in most cases, developed by multifamily residential settlements. Since 1950 they took place of vine and fruit growing. Zoning plans, executed since 1960, have shaped the city as a concentric layout, were several zones may be distinguished: close center, downtown, suburbs and peripheral.

By analyzing the distribution of post-mining areas and former coal mines in the city of Zielona Gora, in relation to the findings of the planning documents shaping the directions of its development within the urban spatial policy, it must be assumed that the mentioned areas and the effects of their operation are not reflected in any planning document, or any other strategic document, affecting the way of planning the development and growth of Zielona Góra (fig. 2). Conditions arising from the functioning of the mines and the mining areas "United Mines of Zielona Góra" have not reflected also in the supporting documents, such as the ecophysiographic studies and the estimation of an impact of planning documents on the environment, on the stage of the procedure planning, where, inter alia, in accordance with the will of the legislator the way the management of areas degraded by human activity is specified, including requiring remediation, which should also include land after extraction of coal [1].



Fig. 2. Post-mining areas and former mine sites within the administrative boundaries of Zielona Góra. Source: Zielona Góra City Hall

Rys. 2. Tereny pogórnicze i pokopalniana w granicach administracyjnych miasta Zielona Góra. Źródło: Urząd Miasta Zielona Góra 
The planning documents of Zielona Góra do not suggest the fact that within the administrative boundaries of the city there were areas of extraction of lignite, neither in the conditions, nor the elements with the historical and cultural value that are possible to be set in space, and even more so in the arrangements for the city development directions. None of these documents also indicates these areas as potential areas of threat to new construction.

\section{Soil remediation}

The order of issuing administrative decisions - concession for extraction of minerals and the decision establishing the direction of remediation is defined by the provision of article 129 paragraph 2 of the Act of 9 June, 2011. Geological and Mining Law (Off. J. of 2016 item 1131) [17] provides that the land reclamation after mining activities, is done under the provisions of the Farm and Woodland Conservation Act of 3 February 1995 (Off. J. of 2015 item 909 as amended) [16]. In the current legal status, the County Governor, acting on the basis of art. 22 of the Farm and Woodland Conservation Act, may impose obligations concerning the rehabilitation of land, where mineral resources had been extracted, both on the active mining companies, which intend to close down the mining plant, in whole or in part, and also on the former, already closed companies.

In accordance with article 20 paragraph 4 of the act, a remediation of the land shall be run gradually as the land is becoming redundant - wholly, partly, or for a time limited to running industrial activities, and it shall end within 5 years after ceasing the activity. On the basis of the article 22 paragraph 1 of the mentioned act decisions on reclamation and land use shall specify:

a) the degree of limitation or loss of value of land, as determined on the basis of the opinion;

b) the person obliged to run the reclamation of land;

c) the direction and the deadline of the reclamation;

d) regarding the reclamation as finished.

Therefore, the obligation to reclamation and determining direction of reclamation, cannot be imposed before appearance of such an obligation because in accordance with article 5 subpar. 18 of the act - a remediation is understood as giving or restoring value in use or natural value of degraded land by appropriate shaping the terrain, improving its physical and chemical properties. This means that the concession for the exploitation of the deposits should appear first in the legal circulation, the decision determining the direction of remediation should be made later.

The remediation of the area of a former or illegal exploitation of minerals, in case of the property owner's change, in accordance with the formal and legal requirements, including the article 20 paragraph 1 of the Farm and Woodland Conservation Act of 3 February 1995 (Off. J. of 2015 item 909 as amended) [16], is an obligation, at the own expense, of the person causing the loss or limi- 
tation of the land value in use. On this basis, the County Governor shall issue a decision ordering the execution of remediation. In accordance with article 20 paragraph 6 of the mentioned act, in case of a change of the person liable for the land remediation, by decision of the competent authority, referred to in art. 5, the rights and obligations arising from the previously released decisions are transferred. The provisions do not specify the extent to which the entity obliged to remediate controls the remediated land and what is his legal status in relation to the property when there is no contractual relationship concerning the property with its owner or autonomous possessor.

It therefore has to be concluded that in the current legislation, fulfilling the obligations in terms of a remediation, which are imposed by administrative decision, does not justify the assumption that the unit running the remediation becomes the owner of the land, within the meaning of article 2 paragraph 1 subparagraph 4 of the act of 12 January 1991 on taxes and fees. (Off. J. of 2014 item 849 as amended) [10] and the article 336 of the act of 23 April 1964 - Civil Code (Off. J. of 2016 item 380 as amended) [12].

The property owner is obliged to allow the person making the reclamation an access to the land and the execution of the obligations imposed due to the reclamation. After this period, a decision on completion of the remediation can be made. During this period the owner controls the property.

The degree of reduction or loss of land value in use, in the context of the heading remediation, is specified by the person preparing the appraisal (valuer), in accordance with article 28 paragraph 5 of the Farm and Woodland Conservation Act of 3 February 1995 (Off. J. of 2015 item 909 as amended.) [16], which indicates the need for reliance on two separate opinions of valuers. It should be assumed that a valuer may be any natural person, legal person or an organizational unit, which has the expertise in this area. It can also be a scientific institution. The selection of a valuer is made by the decision-making authority. The subject of the appraisals should be to determine the degree and extent of a reduction or loss of agricultural land's value in use.

\section{Conclusions}

The problem of the former mine sites of Zielona Gora, however, is that the lands were not marked and listed in the strategy documents of the city or neighboring municipalities. The problem of the land of former mine sites is not regulated, in this case, by the provisions resulting, inter alia, from the Act of 16 April 2004 on the protection of nature (Off. J. of 2015 item 1651 as amended) [11] and the Act of 24 April 2015 on amending certain laws due to the strengthening of the tools for landscape protection (Off. J. of 2015 items 774, 1688) [13], nor the Farm and Woodland Conservation Act of 3 February 1995 (Off. J. of 2015909 as amended) [16], although their effects are regulated by article 86 of the Consti- 
tution of the Republic of Poland [8] stating that the recovery of all elements of the natural environment is the constitutional responsibility [6].

The lack of regulation in this area is particularly important, since mining activities has unfortunately often been perceived negatively by the public, especially outside Silesia. Such an opinion is the effect of previous decades, when the issues of remediation and protection of the environment were not always given enough attention. Negligence from previous periods, however, are systematically being eliminated. However, the negative attitude of the society could be seen, for instance in preventing the possibility of setting up an open-pit lignite mine in Gubin (strategic resources of lignite for Lubuskie region), where the main problem of the public consultations concerning the establishment of lignite extraction zones in Gubin, was the lack of experience and knowledge of the superior institutions, carrying out the consultations on the process of inhabitants' participation. Activities have been virtually limited to talks about mine foundation, mining schedule, employment growth and personal assets liquidation, without the appraisal of their real values. The social and economic consequences of the establishment of a lignite mine also has not been properly assessed. Such an attitude resulted in a protest and objection of the inhabitants of Gubin municipality, against the mine establishment.

Currently, there are no regulations to ensure coherence of activities for post-mining land development with the objectives of the zoning plans and the requirements of the deposits protection. It seems that the presented legal loopholes and the lack of the promotion of activities towards remediation of postmining areas are the basic obstacle to acceptance of changes to new mining areas by the public.

An independent aspect, resulting from the situation in the city of Zielona Góra, is the fact that the land were lignite used to be mined, in accordance with the law is not agricultural land. Legally, they are not recognized as post-mining areas and former mine sites, therefore, the regulations relating to the efforts to restore their environment and treating them as the land degraded by a human activity, also those which require remediation, are not a base for a policy of their development and destination.

\section{References}

[1] Bazan-Krzywoszańska A.: Rozwój społeczno-przestrzenny Zielonej Góry po 1945 roku: dynamika rozwoju od miasta małego do miasta średniej wielkości, Oficyna Wydawnicza Uniwersytetu Zielonogórskiego, Zielona Góra 2013.

[2] Bazan-Krzywoszańska A., Greinert A., Skiba M.: Stan prawny działań rekultywacyjnych w Polsce, [w:] Wydobycie węgla brunatnego i rekultywacja terenów pokopalnianych w regionie lubuskim, red. A. Greinert, Zielona Góra, Instytut Inżynierii Środowiska Uniwersytetu Zielonogórskiego, 2015, s. 275-287. 
[3] Gontaszewska A.: Kopalnia węgla brunatnego "Borussia" koło Ośna Lubuskiego, [w:] Zeszyty Naukowe Uniwersytetu Zielonogórskiego. Inżynieria Środowiska. Nr 162 (42), 2016, s. 89-101.

[4] Gontaszewska A.: Zarys historii górnictwa węgla brunatnego w okolicy Ośna Lubuskiego i Sulęcina (Ziemia Lubuska), Hereditas Minariorum, 2, 2015, 51-65, www.history-of-mining.pwr. wroc. pl (data dostępu: 10.11.2016).

[5] Gontaszewska A., Kraiński A.: Złoża węgla brunatnego na terenie gminy Świdnica, Zielona Góra 2008, s. 47, http://journals.bg.agh.edu.pl/GORNICTWO/201103/GG_2011_3_09.pdf (data dostępu: 10.11.2016).

[6] http://geoportal.pgi.gov.pl/geosam/ekspert_odpowiada/zloza_2013/rekultywacja (data dostępu: 10.11.2016).

[7] Kasztelewicz Z., Sypniowski Sz.: Kierunki rekultywacji w Polskich kopalniach węgla brunatnego na wybranych przykładach, Górnictwo i Geoinżynieria, Rok 35, Zeszyt 3, 2011.

[8] The Constitution of the Republic of Poland of 2 April 1997. Off. J. of 1997. no 78, item. 483 - as amended).

[9] Nita J., Myga-Piątek U.: Krajobrazowe kierunki zagospodarowania terenów pogórniczych, Przegląd Geologiczny, vol. 54, nr 3, 2006, https://www.pgi.gov.pl/images/ stories/przeglad/pdf/pg_2006_03_25.pdf (data dostępu: 10.11.2016).

[10] The act of 12 January 1991 on taxes and local fees. (Off. J. of 2014 item 849 as amended).

[11] The act of 16 April 2004 on the protection of nature (Off. J. of 2015 item 1651 as amended).

[12] The act of 23 April 1964. - Civil Code (Official Journal of 2016 item 380 as amended.

[13] Act of 24 April 2015, amending certain laws in connection with the strengthening of the tools of landscape protection (Off. J. of $2015 \mathrm{r}$. item 774, 1688).

[14] Act of 27 April 2001, the Environmental protection law (Off. J. of 2016, item 672 - as amended).

[15] The act of 27 March 2003 on spatial planning and development (Off. J. of 2016. 778 - as amended).

[16] Farm and Woodland Conservation Act of 3 February 1995 (Off. J. of 2015 item 909 as amended).

[17] The Act of 9 June, 2011 Geological and Mining Law (Off. J. of 2016 item 1131).

\section{POLITYKA ZAGOSPODAROWANIA TERENÓW POGÓRNICZYCH NA PRZYKŁADZIE MIASTA ZIELONA GÓRA}

\section{Streszczenie}

Artykuł jest wprowadzeniem w problematykę kształtowania obszarów pogórniczych i terenów pokopalnianych okolic miasta Zielona Góra (województwo lubuskie). Jednym z charakterystycznych procesów geologicznych, kształtujących obecną powierzchnię ww. obszaru były zaburzenia glacitektoniczne - zespół procesów związanych z działalnością lądolodów, które umożliwiły wyniesienie w pobliże powierzchni terenu pokładów węgla brunatnego. Pozwoliło to w przeszłości na ich częściową eksploatację. W XIX wieku, w okolicy Zielonej Góry, działało wiele 
kopalni węgla brunatnego. Niektóre z nich zostały już zupełnie zapomniane i nie zachowały się po nich żadne dokumenty lub informacje stanowiące potwierdzenie faktu ich wcześniejszego istnienia. Obecnie najważniejszym surowcem naturalnym okolic miasta są kruszywa naturalne w postaci piasków i żwirów oraz różnego rodzaju surowce ceramiczne (iły, gliny).

Miasto Zielona Góra poszukując nowych terenów inwestycyjnych, zagospodarowuje kolejne obszary, w tym również te, które są terenami pokopalnianymi od co najmniej 70 lat. Nie przeprowadzono na nich rekultywacji, zgodnej z obecną procedurą przyjętą na mocy obowiązujących przepisów prawa. Chociaż rekultywacja terenów pogórniczych, zarówno techniczna, jak i biologiczna, jest obowiązkiem zakładu górniczego i powinna być zgodna z przepisami prawa, to od ponad 70 lat nie istnieją instytucje objęte ww. obowiązkiem.

Wartość historyczna terenów pogórniczych miasta, jak również problematyka związana z ochroną przyrody i krajobrazu, wynikająca między innymi z zapisów ustawy z dnia 16 kwietnia 2004 r. o ochronie przyrody (Dz. U. z 2015 r. poz. 1651 - t.j. z późn. zm.) [11] oraz ustawy z dnia 24 kwietnia 2015 r. o zmianie niektórych ustaw w związku ze wzmocnieniem narzędzi ochrony krajobrazu (Dz. U. z 2015 r. poz. 774, 1688) [13], wskazują na potrzebę działań, mających na celu zachowanie funkcji dokumentacyjnej i podtrzymującej tożsamość miejsca. Dla takich przestrzeni można przewidzieć różnego rodzaju sportowo-rekreacyjne lub np. parkowe ich wykorzystanie [9]. Przede wszystkim jednak konieczne jest ustalenie kierunków rozwoju, w ramach dokumentów kształtujących miejską politykę przestrzenną, wskazującą na przeznaczenie i sposób zagospodarowania ww. terenów.

Słowa kluczowe: zagospodarowanie terenu, polityka miejska, dokumenty planistyczne, tereny pogórnicze i pokopalniane

Przestano do redakcji: $15.02 .2017 \mathrm{r}$.

Przyjęto do druku: 30.06 .2017 r. 